\title{
PepT1 mRNA expression levels in sea bream (Sparus aurata) fed different plant protein sources
}

\author{
Genciana Terova ${ }^{1,2^{*}}$, Lidia Robaina ${ }^{3}$, Marisol Izquierdo $^{3}$, AnnaGiulia Cattaneo $^{1}$, Silvia Molinari ${ }^{1}$, \\ Giovanni Bernardini $i^{1,2}$ and Marco Saroglia, ${ }^{1,2}$
}

\begin{abstract}
The expression and regulation of intestinal oligopeptide transporter (PepT)-1 when vegetable sources are used as a substitute for fish meal in the diet of marine fish has not yet been explored. In the present study, as part of our ongoing work on elucidating PepT1 gene expression in relation to different dietary treatments, we have now isolated and deposited in Genbank database (accession no. GU733710) a cDNA sequence representing the PepT1 in the sea bream (Sparus aurata). The "de novo" prediction of the three-dimensional structure of PepT1 protein is presented.

We also analyzed diet-induced changes in the expression of PepT1 mRNA via real-time RT-PCR using the standard curve method. Sea bream were fed for 140 days with one of the following four diet formulations (43\% protein/21\% lipid): a control fast growth-promoting diet (C), and three diets with the same formulation but in which 15\% of the fish meal was substituted by protein concentrates either from lupine (LPC), chick pea (CPC), or green pea (PPC). Fish fed PPC had significantly $(p<0.05)$ lower levels of PepT1 transcripts in the proximal intestine than the controls, whereas PepT1 transcript levels in fish fed LPC or CPC were not significantly different from the controls. Although growth was similar between fish fed with different diets during the first 72 days of feeding, growth of the fish fed with PPC was reduced during the second part of the trial and was significantly $(p<0.05)$ lower than fish fed LPC and CPC diets by the end of the experiment. Correlation between these results and fish growth performances highlights that the intestinal PepT1 mRNA level may serve as a useful marker of the dietary protein quality and absorption efficiency.
\end{abstract}

Keywords: Oligopeptide transporter PepT1, Gene expression, Real-time PCR, Fish meal substitution, Vegetable ingredients, Fish diet, Aquaculture

\section{Introduction}

The end products of intestinal protein digestion in both teleosts and mammals constitute a mixture of free amino acids and small peptides that are efficiently absorbed across the small intestinal epithelium (Clements \& Raubenheimer 2006). Two distinct types of brush border membraneassociated transport systems are involved in this process: (1) amino acid transport, which may or may not be sodium dependent; and (2) transport of small peptides (2-3 amino acids) coupled to an $\mathrm{H}^{+}$gradient. Intestinal peptide

\footnotetext{
* Correspondence: genciana.terova@uninsubria.it

'Department of Biotechnology and Life Sciences, University of Insubria, Via J. H. Dunant, 3 - 21100, Varese, Italy

${ }^{2}$ Inter-University Centre for Research in Protein Biotechnologies "The Protein Factory"- Polytechnic University of Milan and University of Insubria, Varese, Italy

Full list of author information is available at the end of the article
}

transport is of major nutritional significance in that the intraluminal products of protein digestion are predominantly di- and tripeptides, not amino acids as was widely believed over 30 years ago (Adibi 2003).

Cellular uptake of small peptides is mediated by $\mathrm{H}$ +/coupled peptide transporter (PepT1), located at the brush border membrane of intestinal epithelial cells (Yuen et al. 2007). PepT1 is a low-affinity, high-capacity transporter that mediates electrogenic uphill transport of di- and tripeptides from the apical membrane of the epithelial cells into the enterocytes. The transport is energized by a transmembrane electrochemical $\mathrm{H}+$ gradient directed from outside to inside. PepT1 has nutritional importance due to its dual role in intestinal absorption of a remarkable range of dietary protein-derived substrates and in reabsorption of

\section{里}

(C) 2013 Terova et al.; licensee Springer. This is an Open Access article distributed under the terms of the Creative Commons Attribution License (http://creativecommons.org/licenses/by/2.0), which permits unrestricted use, distribution, and reproduction in any medium, provided the original work is properly cited. 
peptide-bound amino nitrogen from glomerular filtrate in kidney (Daniel \& Kottra 2004).

The gene encoding the proton-coupled di- and tripeptide transporter PepT1 was isolated first from rabbit small intestine. Fei et al. (Fei et al. 1994) cloned it in 1994 by microinjecting mRNA isolated from rabbit intestine into Xenopus oocytes, which resulted in functional expression of the protein. In subsequent years, PepT1 was characterized in great detail in higher vertebrates [mostly in mammals, but also in birds (for a review please see (Daniel et al. 2006). In contrast, information about this protein in lower vertebrates such as teleosts is limited, with the exception of PepT1 of the zebrafish (Danio rerio), Atlantic cod (Gadus morhua), Asian weatherloach, (Misgurnus anguillicaudatus), and sea bass (Dicentrarchus labrax). The functional activity and tissue expression pattern of PepT1 have been assessed in these species (Verri et al. 2003; Rønnestad et al. 2007; Gonçalves et al. 2007; Terova et al. 2009).

The affinity of PepT1 and its stereoselective capacity differ for different types of peptides, suggesting that its activity and expression may be modulated through the diet, particularly when different protein sources are utilized (Ostaszewska et al. 2010a; Ostaszewska et al. 2010b). However, to our knowledge, there is no information regarding the response at the mRNA level of such transporter when vegetable sources are used as a substitute for fish meal in the diet of marine fish.

Fish meal (FM) supply has become a limiting factor for the further development of fish feed production. Total annual world FM production is about 5-6 million tons (FAO 2010) and is predicted to remain stable for the next 10 years (Mazurkiewicz 2009). Increased FM cost, together with the limited availability, has encouraged the use of alternative sustainable sources of protein in fish feeds in the last few decades (Tacon \& Metian 2008; Kaushik \& Seiliez 2010). Thus, high rates of several terrestrial plant meals have been successfully included in the feed without affecting fish growth and production quality (Carter \& Hauler 2000; Aslaksen et al. 2007; SánchezLozano et al. 2011). Nevertheless, plant protein sources differ greatly in nutritional value, not only as regards their amino acid profiles and digestibility but also their carbohydrate content and characteristics or the processing method (Francis et al. 2001; Drew et al. 2007; Gatlin et al. 2007; Glencross et al. 2007). Therefore, the degree of success differs for different types of plant proteins. Among these sources, protein concentrates of pea (Pisum sativum), lupin (Lupinus spp.), or chick pea (Cicer arietinum) have been considered as good candidates for replacing fish meal. For instance, including up to $20 \%$ pea protein concentrate has been reported to support acceptable weight gain, feed intake, and feed conversion ratios in Atlantic salmon (Carter \& Hauler 2000), rainbow trout (Thiessen et al. 2003), or sea bream (Sánchez-Lozano et al. 2011).
Accordingly, in the present study we first cloned a cDNA encoding PepT1 in gilthead sea bream and then assessed the impact of different feeds in which various vegetable sources substituted the fish meal on PepT1 mRNA levels in the proximal intestine of sea bream (Sparus aurata) with the aim to relate these expression levels to fish performance during the feeding trial.

\section{Materials and methods}

\section{Feeds, fish and feeding protocol}

Sea bream of about $92 \mathrm{~g}$ initial average weight were stocked into 500 litter fibreglass tanks at a density of 25 fish $\operatorname{tank}^{-1}$. Experiment was carried out in an open circulation system under natural photoperiod of about 12/12 dark/light. Temperature and oxygen concentrations measured during the trial ranged between 19.4 to $23.5^{\circ} \mathrm{C}$ and 6 to $7 \mathrm{ppm}$, respectively. Fish were fed to apparent satiation in triplicate groups for 140 days with one of the experimental diets. A fast growth promoting control diet (C) was prepared according to a basal commercial formulation (Dibaq Diproteg, Segovia, Spain) containing a regular composition of about $40 \%$ fishmeal and fish oil content and a mix of products and by products from cereals and oilseeds $(50 \%)$, mainly soybean and wheat, and a remaining $10 \%$ for the vitamin and mineral premixes, antioxidants and antifungal components. A $15 \%$ of the fishmeal in this basal formula was substituted by protein concentrates from lupine (diet LPC), chickpea (diet CPC) or green pea (diet PPC). All diets were produced at a commercial scale by Dibaq and were extruded throughout a $4 \mathrm{~mm}$ die size. Diets were isoproteic and isocaloric and their proximate composition is shown in Table 1. Feed biochemical composition analyses were conducted following standard procedures (AOAC. Available on line at: http:// www.eoma.aoac.org/methods/search.asp?string=b). Dry matter content was determined after drying the sample in an oven at $105^{\circ} \mathrm{C}$ to constant weight, ash was determined by combustion in a muffle furnace at $600^{\circ} \mathrm{C}$ for $12 \mathrm{~h}$, protein content (Nx6.25) was determined by Kjeldahl method and crude lipid was extracted following the method of Folch et al. (Folch et al. 1957).

The fish were fed ad libitum 6 days a week in the following manner: food for each tank was weighed separately and placed in a container: the feed from each container was

Table 1 Proximate composition of the experimental diets feed containing test ingredients

\begin{tabular}{lccc}
\hline & LPC & PPC & CPC \\
\hline Protein (\%) & 46.02 & 45.37 & 45.30 \\
Lipid (\%) & 20.83 & 20.64 & 20.04 \\
Ash (\%) & 7.74 & 8.08 & 7.66 \\
Moisture (\%) & 6.45 & 7.68 & 6.52 \\
\hline
\end{tabular}


given in the morning (08:00) by hand, in small quantities until the fish ceased to respond; in the afternoon (15:00) the process was repeated; at the end of the day all the feed left in each container was weighed and the feed consumption of each tank was then registered. Feed conversion (g fish weight gain/g feed eaten) and specific feeding rates (daily fish feeding) were then calculated.

All fish were individually weighted at the beginning of the feeding trial and after 35, 72, 112 and 140 days of feeding the experimental diets. Weight data were analyses statistically by using the SPSS (13.1) statistical package. The level of statistical significance was set at 0.05 . At the end of the trial, 5 fish from each tank were sacrificed. For the molecular biology analysis, the whole intestine was sampled and then dissected out in 7 equal segments of about $2 \mathrm{~cm}$ each. In addition, other tissues such as stomach, brain, muscle, and spleen were also isolated, frozen immediately in liquid nitrogen and then stored at the temperature of $-80^{\circ} \mathrm{C}$ until the analysis. All procedures were approved by the Animal Care Committee of the University of Las Palmas de Gran Canaria and conducted according to the guidelines of the Italian Committee on Animal Care.

\section{Preparation of total RNA, cDNA synthesis, sea bream PepT1 cloning and sequencing}

Total RNA was extracted from sea bream proximal intestine using PureYield RNA Midiprep System (Promega, Italy), following the protocol described in PureYield ${ }^{\mathrm{Ts}}$ RNA Midiprep System Technical Manual \#TM279, available online at: www.promega.com/tbs. This kit isolates intact, pure total RNA from essentially any sample type for use in a wide range of applications. The use of a novel Clearing Agent enables the rapid purification of total RNA with undetectable levels of genomic DNA contamination without using DNase. A novel combination of reagents, membranes and protocol leads to yields of up to $1 \mathrm{mg}$ of total RNA without organic solvents, protease digestions or alcohol precipitations.

The quantity of the extracted RNA was calculated using the absorbance at $260 \mathrm{~nm}$, whereas the integrity of RNA was assessed by agarose gel electrophoresis. Crisp $18 \mathrm{~S}$ and $28 \mathrm{~S}$ bands, detected by ethidium bromide staining were indicator of the intact RNA.

After extraction, total RNA was reverse transcribed into cDNA in a mix containing oligo dT16 primer, and dNTPs. This mix was heated, chilled on ice, and then reverse transcription buffer, DTT, RNaseOUT, and Moloney murine Leukaemia virus reverse transcriptase were added, as described in the M-MLV Reverse Transcriptase kit (Invitrogen).

To perform PCR, an aliquot of the resulting cDNA was amplified with GoTaq Polymerase (Promega) in a final volume containing buffer, dNTPs, and the primer set (sense + antisense) designed by us (Table 2). To design the primers, we firstly performed a BlastN search (http:// www.ncbi.nml.nih.gov/BLAST/) for orthologues of PepT1 gene in other fish/vertebrate species. A multiple nucleotide sequence alignment (http://www.ebi.ac.uk/Tools/ msa/clustalw2/) was then carried out on the sequences found and regions of strong nucleotide conservation were used to design the primers.

The PCR amplifications were performed for PepT1 sense 1 + antisense1, and for PepT1 sense 2 + antisense 2 primer sets, using an automated Thermal Cycler (Mycycler, Biorad). An aliquot of each PCR reaction was then electrophoresed on agarose gel and bands were detected by ethidium bromide staining. The PCR products from PepT1 primer amplifications were then cloned using the pGEM $^{\circledR}$-T Easy cloning vector system (Promega, Italy) and subsequently sequenced in both directions (T7 and SP6).

\section{Quantitative real-time RT-PCR \\ Generation of in vitro-transcribed PepT1 mRNAs for standard curves}

The number of PepT1 gene transcript copies were absolutely quantified by comparing them with a standard graph constructed using the known copy number of mRNA of this gene. For this, a forward (PepT1_T7promoter) and a reverse (PepT1_antisense3) primer were designed based on the mRNA sequences of Sparus aurata PepT1 after its identification (accession no. GU733710) (Table 2). This primer pair was used to create templates for the in vitro transcription of mRNAs for PepT1. In vitro transcription was performed using T7 RNA polymerase and other reagents supplied in the Promega RiboProbe In Vitro Transcription System kit according to the manufacturer's protocol.

The molecular weight (MW) of the in vitro-transcribed RNA for each gene was calculated according to the following formula:

$\mathrm{MW}=\left(\mathrm{n}^{\circ}\right.$ of $\mathrm{A}$ bases $\left.\times 329.2\right)+\left(\mathrm{n}^{\circ}\right.$ of $\mathrm{U}$ bases $\left.\times 306.2\right)+$ $\left(n^{\circ}\right.$ of C bases $\left.\times 305.2\right)+\left(n^{\circ}\right.$ of $G$ bases $\left.\times 345.2\right)+159$.

Table 2 Sequences of the primers used in the work

\begin{tabular}{|c|c|c|}
\hline Primer & Sequence $5^{\prime}-3^{\prime}$ & Purpose \\
\hline PepT1-sense1 & GATGACTTCGCCACCACTA & RT-PCR \\
\hline PepT1-antisense1 & CGATCAGATGCAGACGGTG & RT-PCR \\
\hline PepT1-sense2 & AGCAGGGCTCAAGATGGAC & RT-PCR \\
\hline PepT1-antisense2 & ACATCATCGTGCTCATCGTG & RT-PCR \\
\hline PepT1_T7promoter & $\begin{array}{l}\text { gtaatacgactcactataggg } \\
\text { GGAGTGTGGTATTCACA }\end{array}$ & mRNA std.curve \\
\hline PepT1_antisense3 & AGCAGGGCTCAAGATGGAC & mRNA std.curve \\
\hline PepT1 - sense & GCTACCCTCTGGCCTITGG & Real-time \\
\hline PepT1 - antisense & ATGGTGGTAGCTCTGATTGTGTTC & Real-time \\
\hline Taqman PepT1 & TCCCCGCTGCTCTC & Real-time \\
\hline
\end{tabular}


The mRNAs produced by in vitro transcription were then used as quantitative standards in the analysis of experimental samples using one-step TaqMan EZ RT-PCR Core Reagents (Life technologies, Italy). RT- PCR conditions were: $2 \mathrm{~min}$ at $50^{\circ} \mathrm{C}, 30 \mathrm{~min}$ at $60^{\circ} \mathrm{C}$, and $5 \mathrm{~min}$ at $95^{\circ} \mathrm{C}$, followed by 40 cycles consisting of $20 \mathrm{~s}$ at $92^{\circ} \mathrm{C}, 1 \mathrm{~min}$ at $62^{\circ} \mathrm{C}$. The $\mathrm{Ct}$ values obtained by amplification were used to create standard curves for target genes.

\section{Quantitation of PepT1 transcripts by one-step RT-PCR TaqMan system}

A hundred nanograms of total RNA extracted from the experimental samples was subjected, in parallel to 10-fold-diluted, defined amounts of standard mRNA, to real-time PCR under the same experimental conditions as for the establishment of the standard curves. Real-time Assays-by-Design $^{\text {SM }}$ PCR primers and gene-specific fluorogenic probes were designed by Life technologies (LT). TaqMan ${ }^{\circledR}$ PCR was performed on a StepOne Real Time PCR System (LT, Italy). Data from Taqman ${ }^{\circledR}$ PCR runs were collected with StepOne's Sequence Detector Program. The reaction efficiency was in the range 88-90\%. Furthermore, a minus-reverse transcriptase control ("No Amplification Control" or NAC) was included in qRT-PCR experiments. The NAC was a mock reverse transcription containing all the RT-PCR reagents, except the reverse transcriptase. No product was seen in the NAC, which indicates that contaminating DNA was not present in the sample.

\section{Calculation and statistical analysis}

The data were statistically compared using one-way analysis of variance (ANOVA). The level of statistical significance was set at $\mathrm{p}<0.05$.

\section{In silico analysis}

The amino acid sequence of sea bream PepT1 (GenBank accession number GU733710.1) was analyzed using the open reading frame (ORF) finder program which is available at NCBI (http://www.ncbi.nlm.nih.gov). Nucleotide sequence was compared with other sequences available at the GenBank database using the BLAST algorithm (Altschul et al. 2003). Sequences were aligned using the ClustalW program (www.ebi.ac.uk/clustalw) and Multiple Sequence Alignments Editor \& Shading Utility, GeneDoc, version 2.6.002 (www.psc.edu/biomed/genedoc).

\section{Protein annotation}

The partial putative amino acid sequence of sea bream (Sparus aurata) PepT1 (Genbank accession no. ADE58426.1) was compared with the complete sequence of sea bass (Dicentrarchus labrax) that we previously isolated (GenBank accession no. ACI49693.2) (Terova et al. 2009). Owing to the high similarity of the two sequences, the analyses for annotation at the MemPype server (http:// mu2py.biocomp.unibo.it/mempype) (Pierleoni et al. 2011) and at the Interpro 33.0 (https://www.ebi.ac.uk/interpro/) (Hunter et al. 2012) were performed on the primary structure of D. labrax PepT1. We also submitted the structures to the SMART service for predicting similar domains (http://smart.embl-heidelberg.de/) (Letunic et al. 2009; Schultz et al. 1998).

\section{Tertiary structure}

The protein sequence of sea bass PepT1 aligns partially with only one structure present in the Protein Data Bank (PDB; entry: 2XUT; E-value: 8e-46) (http://www.pdb.org/ $\mathrm{pdb} /$ home/home.do). As the alignment seems to be poor, especially after position 400 up to the C-terminus, its tertiary structure cannot be inferred from that of the template, and a "de novo" prediction of the tertiary structures of the putative proteins was obtained at the I-Tasser server (http://zhanglab.ccmb.med.umich. edu/I-TASSER). The four stages of the method implement a threading procedure followed by structural assembly, refinement of the model, and structurebased functional annotation. The output consists of five models, whose indexes of accuracy are the C score, the TM score, and the RMSD (Roy et al. 2010; Zhang 2007; Zhang 2008).

The tertiary structure-based COFACTOR algorithm predicted functional insights, including sites for ligand binding. We used the UCSF Chimera software, release 1.5.3 (http://www.cgl.ucsf.edu/chimera/) (Pettersen et al. 2004) to visualize, analyse, and compare the structural models.

\section{Sites for post-translational modifications}

A) Phosphorylation and sumoylation

The serine, threonine, and tyrosine phosphorylation sites were searched at the NetPhos 2.0 server (http://www. cbs.dtu.dk/services/NetPhos/) (Blom et al. 1999); sites for sumoylation were checked with the SUMOsp 2.0 program (http://sumosp.biocuckoo.org/) (Ren et al. 2009).

\section{B) Glycosylation}

The glycosylation sites possibly present in the proteins were searched at the server of the CBS (Center for Biological Sequence Analysis, at the Technical University of Denmark, (http://www.cbs.dtu.dk/services/). Sites for mucin-type mannosyl-O-glycosylation (Net-O-glyc 3.1) (Julenius et al. 2005), C-glycosylation (Johansen et al. 2006) and $\varepsilon$-glycosylation of lysine residues (Julenius 2007) were checked and searched. When sites for $\mathrm{N}$-glycosylation were predicted at the CBS (Net-N-glyc 1.0) (Blom et al. 1999; Blom et al. 2004), a description of their tertiary structure was obtained with the GlyProt application at the Glycosciences server (http://www.glycosciences.de/modeling/). 


\section{Results}

Sea bream PepT1 cDNA sequence

Sea bream PepT1 primer design was based on the alignment of four fish PepT1 coding sequences available on the NCBI Genbank database: Dicentrarchus labrax (accession no. FJ237043), Gadus morhua, (accession no. AY621934), Sebastes nebulosus (accession no. EU160494), and Danio rerio (accession no. AY300011). These presented several conserved regions within the sequence where primers could be reasonably designed.

Two cDNA fragments were obtained using PepT1 sense1 + antisense1 and PepT1 sense $2+$ antisense 2 (Table 2). Then, by connecting the sequences of the partially overlapping clones, a partial coding sequence of $1825 \mathrm{bp}$ for sea bream PepT1 was determined. The cDNA for PepT1 was subsequently deposited in GeneBank under the accession no. GU733710. The deduced amino acid sequence shows that sea bream PepT1 is 608 amino acid long with a calculated molecular mass of approximately $81 \mathrm{kDa}$. Alignment of the amino acid sequence of sea bream PepT1 with that of other teleost, avian, mammalian, and primate species is shown in Figure 1. In the same figure are also indicated the positions of the highly conserved aminoacids.

\section{In silico analysis}

The\% similarities for alignments of PepT1 for different species, including the sizes of protein, are presented in Table 3. The amino acid sequence identity among the species was calculated using the open reading frame. Sea bream PepT1 showed the highest sequence similarity with teleost: (Sea bass: 88\%; Yellow perch: 79\%; Atlantic cod: 68\%; Atlantic salmon, and zebrafish: 69\%; spotted green pufferfish: 65\%; China rockfish: 64\%;) and avian species (chicken, and turkey: 64\%; zebra finch: 60\%), and lower homology with mammalian species (cattle: 62\%;

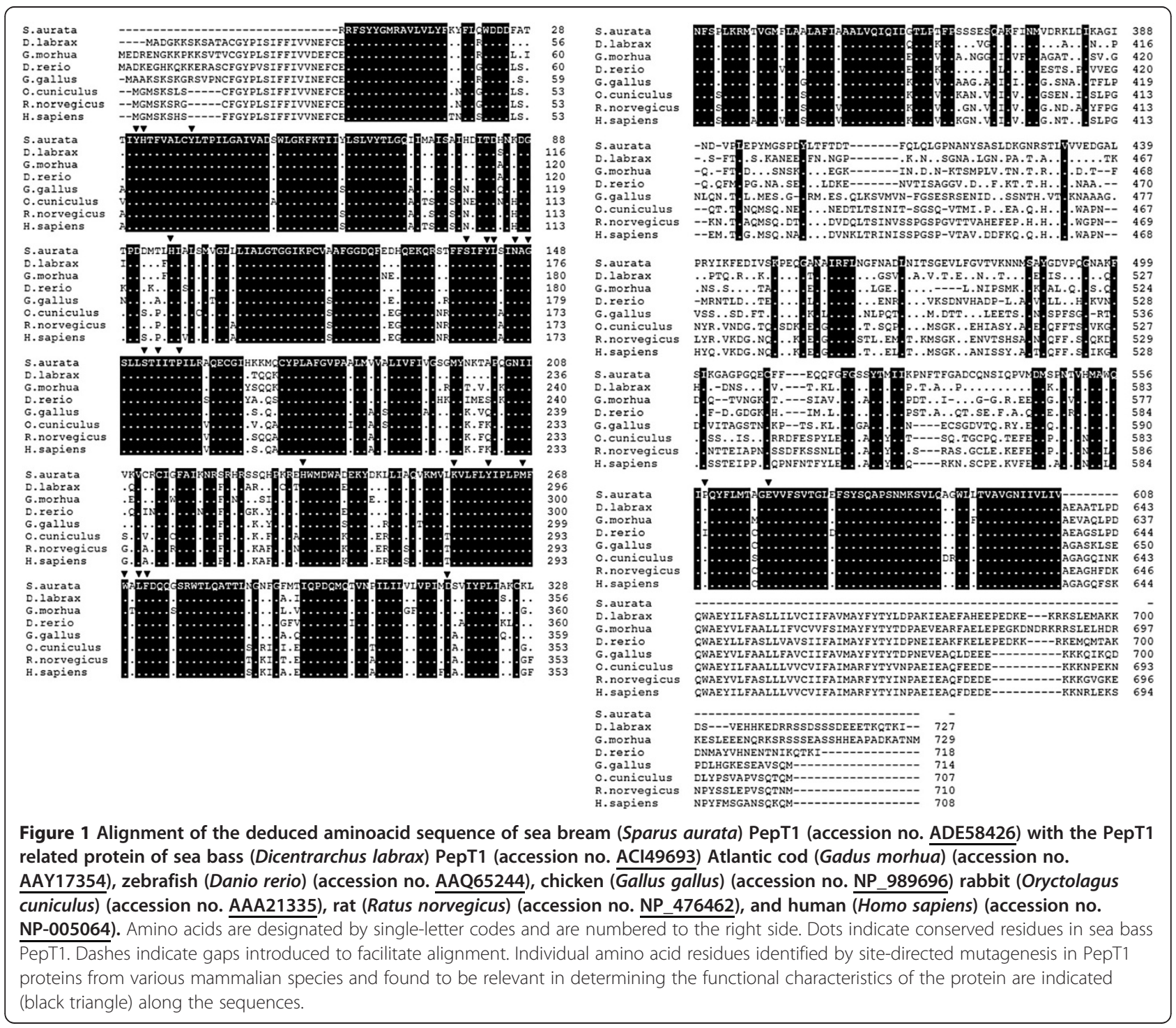


Table 3 Shared identities (\%) between PepT1 proteins in different teleost, avian and mammalian species

\begin{tabular}{|c|c|c|c|c|}
\hline Gene & Species & $\begin{array}{c}\text { GenBank } \\
\text { accession number }\end{array}$ & $\begin{array}{c}\text { Protein } \\
\text { size (aa) }\end{array}$ & $\begin{array}{l}\text { Identity with } \\
\text { S. aurata (\%) }\end{array}$ \\
\hline & Sparus aurata & ADE58426 & 608 & - \\
\hline & $\begin{array}{l}\text { Dicentrachus } \\
\text { labrax }\end{array}$ & ACl49693 & 727 & 88 \\
\hline & Perca flavescens & ACX49753 & 729 & 79 \\
\hline & Gadus morhua & AAY17354 & 729 & 71 \\
\hline & Salmo salar & BAH24102 & 734 & 69 \\
\hline & Danio rerio & XP_001919914 & 717 & 69 \\
\hline & $\begin{array}{l}\text { Sebastes } \\
\text { nebulosus }\end{array}$ & ABV82968 & 742 & 67 \\
\hline & $\begin{array}{l}\text { Tetraodon } \\
\text { nigroviridis }\end{array}$ & CAG05928 & 671 & 65 \\
\hline \multirow[t]{14}{*}{ PepT1 } & Gallus gallus & AAK39954 & 714 & 64 \\
\hline & $\begin{array}{l}\text { Meleagris } \\
\text { gallopavo }\end{array}$ & AAO16604 & 714 & 64 \\
\hline & $\begin{array}{l}\text { Taeniopygia } \\
\text { guttata }\end{array}$ & XP_002196515 & 790 & 60 \\
\hline & Bos taurus & DAA23771 & 707 & 62 \\
\hline & Equus caballus & XP_001493109 & 789 & 61 \\
\hline & Callithrix jacchus & XP_002742560 & 797 & 61 \\
\hline & Ratus norvegicus & BAA08844 & 710 & 61 \\
\hline & Ovis aries & AAK14788 & 707 & 61 \\
\hline & $\begin{array}{l}\text { Macaca } \\
\text { fascicularis }\end{array}$ & AAQ56235 & 708 & 61 \\
\hline & Mus musculus & AAl16249 & 709 & 61 \\
\hline & $\begin{array}{l}\text { Ailuropoda } \\
\text { melanoleuca }\end{array}$ & XP_002914915 & 707 & 60 \\
\hline & $\begin{array}{l}\text { Canis lupus } \\
\text { familiaris }\end{array}$ & AAL67837 & 708 & 60 \\
\hline & Sus scrofa & AAO43094 & 708 & 60 \\
\hline & $\begin{array}{l}\text { Oryctolagus } \\
\text { cuniculus }\end{array}$ & P36836 & 707 & 59 \\
\hline
\end{tabular}

horse, common marmoset, rat, sheep, long tail macaque, and mouse: 61\%; giant panda, dog, and pig: 60\%; domestic rabbit: $58 \%$ ).

\section{Protein annotation}

Owing to the high similarity between the partial putative amino acid sequence of sea bream (Sparus aurata) PepT1 (Genbank accession no. ADE58426.1) and the complete sequence of sea bass (Dicentrarchus labrax) PepT1, the analyses for annotation at the MemPype server (http://mu2py.biocomp.unibo.it/mempype) (Pierleoni et al. 2011) and at the Interpro 33.0 (Hunter et al. 2009) were performed on the primary structure of sea bass PepT1. The complete range of bioinformatics analytical tools was used to characterize the PepT1 in this teleost.
The 12 transmembrane domains of sea bass PepT1 protein, predicted by using the TMHMM program (http://www.cbs.dtu.dk/services/TMHMM/), are presented schematically in Figure 2. The Mempype server classified sea bass PepT1 as an internal membrane (confidence score $=95 \%$ ). Similar entries were not found either in the SwissPro or Gene Ontology (GO) servers; therefore, we completed the search at the Interpro 3.3 server. The protein belongs to the proton/oligopeptide transporter 2 (PTR2) family. The corresponding Gene Ontology terms are: 0005215 (transporter activity); 0006857 (oligopeptide transport); and 0016020 (membrane). The PTR domain, recognized by PROSITE (http://prosite.expasy.org/), is located in the region between the $84^{\text {th }}$ and $627^{\text {th }}$ amino acids. It contains two subdomains: PTR2 (position: 73-97) and PTR3 (position 166-178).

\section{Sites for post-translational modifications}

Four sites of possible sumoylation are present at the following amino acid positions: 271, 676, 699, and 726. The PepT1 sequence contains several sites of phosphorylation along the entire chain (Ser: 68\%, Thr: 11\%, Tyr: 21\%). No suitable sites for $\mathrm{C}$-glycosylation were found. Thirteen sites of $\varepsilon$-glycosylation of lysine were predicted (positions 5, 6, 8, $45,114,143,160,199,353,362,542,676$, and 707). The Omannosylation was predicted at positions T330, and T725, and N-glycosylation at sites 120, 227, 357, 498, and 513. Five sites of $\mathrm{N}$-glycosylation were predicted in the primary structure; however, only three of them (position 120, 227 and 357) seemed to be accessible in the tertiary structure of the molecule. It must be noted that, in the absence of the signal peptide, data concerning $\mathrm{O}$ - and $\mathrm{N}$-glycosylation must be interpreted cautiously. All the features are highlighted along the primary structure in Figure 3.

\section{Tertiary structure}

The second model obtained at the I-TASSER server was more consistent with the spatial arrangement of the transmembrane regions and the intra- and extracytoplasmic loops of PepT1 in both fish species taken into consideration. Sea bass and sea bream structural alignment (Figure 4) is largely acceptable; therefore, we used the 3D structure of PepT1 protein obtained in D. labrax as representative for both species. Sea bass Pept1, like all members of the proton-coupled oligopeptide transporter superfamily, is predicted to traverse the membrane 12 times, with amino and carboxyl termini facing the cytosol, and with an elongated extracellular loop connecting the ninth and tenth transmembrane segments (Figures 4, and 5). Several binding sites such as those for phosphate ions and two different types of iron clusters (Figure 6) were predicted based on the similarities with the binding sites of the crystallographically resolved $\mathrm{Pep}_{\mathrm{S}}$ protein from Shewanella oneidensis (Newstead et al. 2011). In 


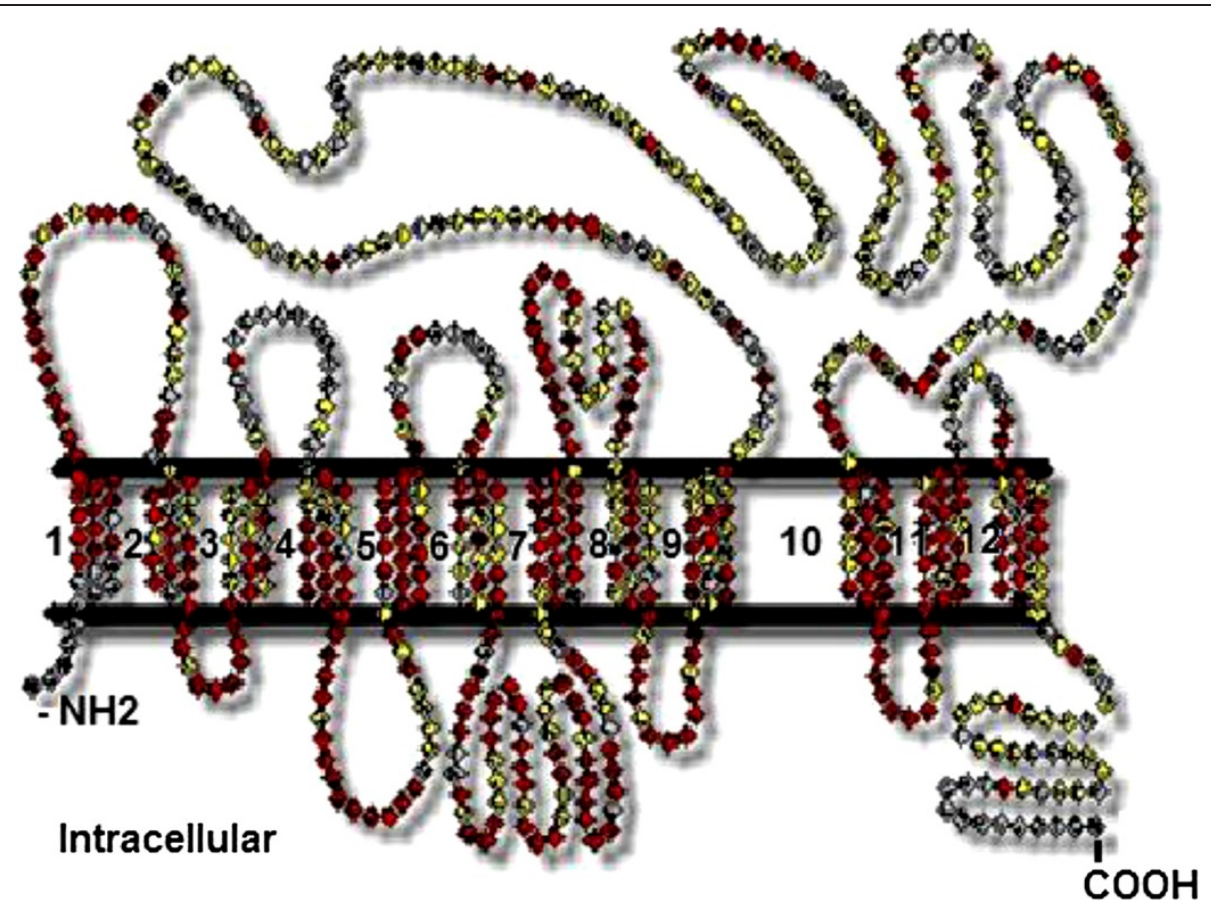

Figure 2 Membrane spanning helices in sea bass PepT1 protein predicted with the THMM program (http://www.cbs.dtu.dk/services/).

Figure 7 are shown three accessible sites for N-glycosylation, reconstructed "in silico" with the addition of oligomannose.

Fish growth and feeding rates

Including plant protein concentrates did not affect feed acceptance. Therefore, we did not find significant differences in total feed intake between diets, with specific feeding rates ranging from 1.06 to 1.18 for the entire period. Although growth was similar between fish fed with different diets during the first 72 days of feeding (Figure 8), growth of the fish fed with PPC was reduced during the second part of the trial and was significantly lower $(\mathrm{p}<0.05)$ than fish fed LPC and CPC diets only at the end of the experiment (Table 4). Subsequently, average feed conversion index was significantly poorest for diet PPC (2.25), in comparison to the other 3 diets (1.90 for LPC and 1.91 for CPC, and C).
Spatial distribution of PepT1 mRNAs in sea bream digestive tract

Total RNA from sea bream tissues was subjected to real-time RT-PCR using the standard curve established for PepT1 mRNA to determine absolute amounts of PepT1 mRNA. To create the standard curve, the correct template length including the T7 promoter was verified by $2 \%$ agarose gel electrophoresis. Quality and purity of mRNAs were confirmed by the ratio of absorptions at $280 / 260$ nm, i.e., $1.8-2.0$ (data not shown). To obtain threshold cycle $(\mathrm{Ct})$ values for the target gene, defined quantities at 10-fold dilutions of PepT1 mRNAs were subjected to a one-tube two-time real-time RT-PCR. The standard curves created for PepT1 were based on the linear relationship between the $\mathrm{Ct}$ value and the logarithm of the starting amount.

This analysis revealed the following spatial distribution of PepT1 gene expression in sea bream digestive tract:

$$
\begin{aligned}
& \text { MADGKKSKSATACGYPISIFFIVVNEFCERFSYYGMRAVLVLYFKYFLRWDDDFATTITYHTFVALCYLTPILGAIVADSW } \quad 80 \\
& \text { LGKFKT IVYLS IVYT LGQ IVMA I SA I HDI T DSNKD G I PDNMT FHVA LSMVGL I L I ALGTGG I KPCVAAFGGDQFEDHQEK } 160 \\
& \text { QRSTFF I I YYLS INAGSLLSTVI TP I LRAQECG I HTQQKCY P LAFGVPAALMVVALIVF IVGSGMYNKTAPQGN I IVQVC } 240 \\
& \text { KCIGFAI KNRFRHRAREHPCRTHWMDWAEEKYY DKLIIAQVKMVLKVLFLYI PLPMFWALFDQQGSRWTLQATTMDGDFGA } 320 \\
& \text { LI I QPDQMQTVNP I LI LVLVP IMDS LVY PLISKCKLNFS PLKRMTVGMFLAALAF IAAALVQIQIDQTLPKF PSSTVGQA } 400 \\
& \text { KF INMVNRALN INAGPNSFTLESYKANEE YFNFNGPFKLNLGSGNAFLGNI PAGTRATIVI IQDGTKPRPTQFRDIKSKP } 480 \\
& \text { EQGTNAIRF LNGFGSVLNATVGTLEFGNTI TNNMSEYISVPQGNAQFHIRDNSGQECVYTQKLGFGSSYTLI IPPTFAFG } 560 \\
& \text { PNCENS IQPVVDI KPNT I HMAWQI PQYFLITAGEVVFSVTGLEFSYSQAPSNMKSVLQAGWLLTVAVGNI IVLIVAEAAT } 640 \\
& \text { LPDQWAEY I LFASLLI IVC I I FAVMAYFYTY్ILDPAKIEAEFAHEEPEDKEKRKSLEMAKKDSVEHHKEDRRSSDSSSDEE } 720 \\
& \text { ETKQTKI }
\end{aligned}
$$

Figure 3 Summary of all the predicted sites of post-translational modification found in PepT1 of D.labrax, shown on the primary sequence. Colour code: phosphorylation indicated as: $\mathrm{S}=$ green, $\mathrm{T}=$ gray, $\mathrm{Y}=$ pink; glycosylation: $\mathrm{N}=$ blue, $\mathrm{e}=$ yellow and $\mathrm{O}=$ purple. Sumoylation sites are underlined. 


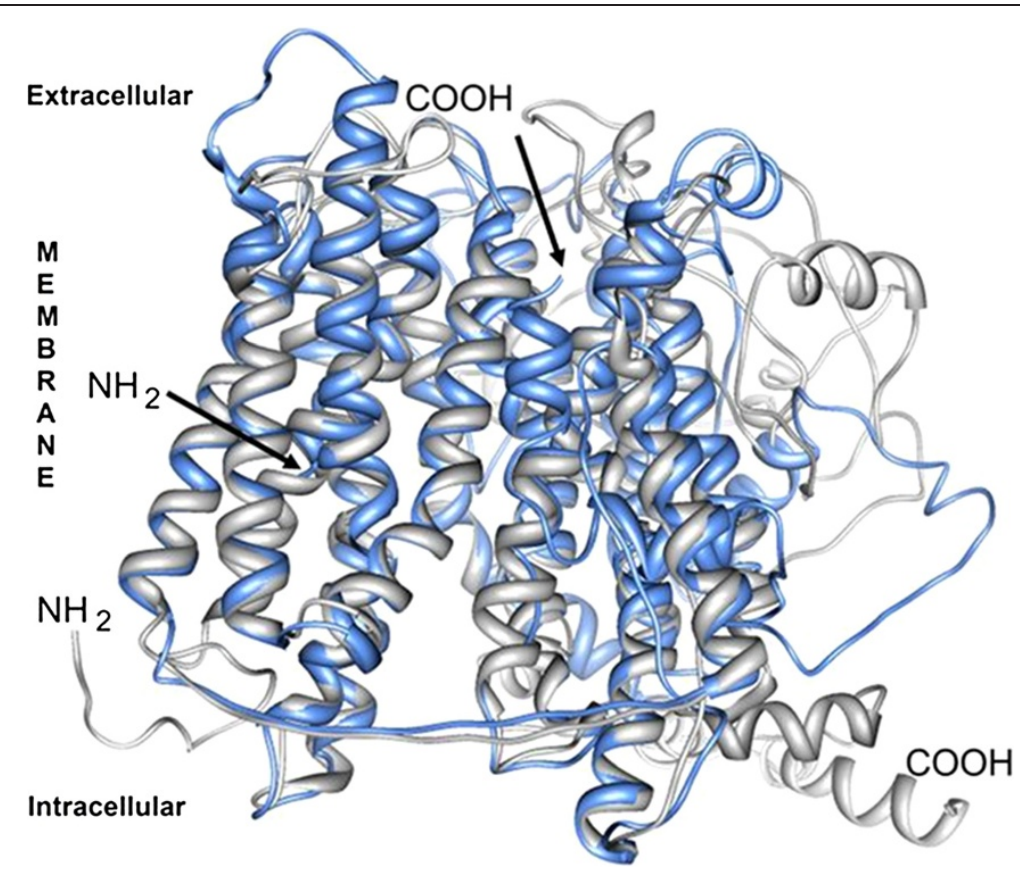

Figure 4 The tertiary structures of the putative proteins PepT1 in S.aurata (partial, blue) and D.labrax (complete, gray) are aligned with the Chimera software.

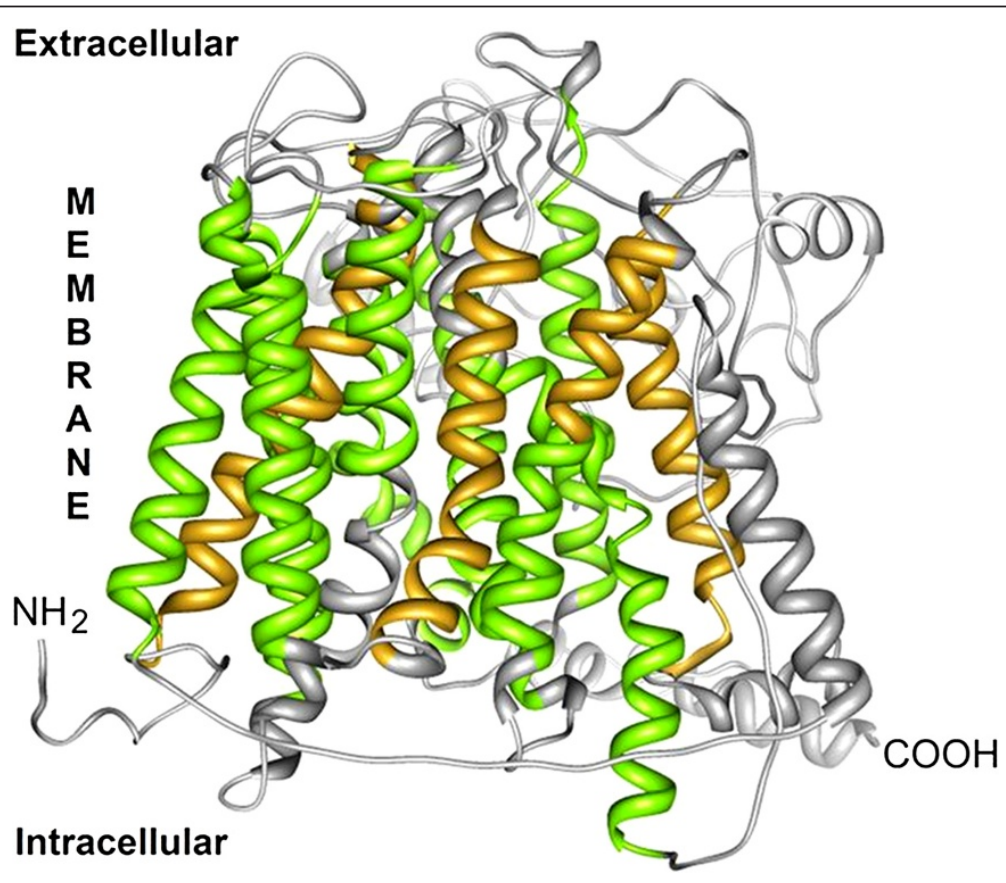

Figure 5 The tertiary structure of the PepT1, predicted at the I-TASSER server, is characterized by 12 transmembrane domains, shaped as alpha helices, and longer enough to completely pass the all thickness of the lipid bilayer (60 vs $45 \AA$ A). The protein starts and ends at the inner side of the bilayer. This feature is typical of channel proteins, to which the PepT1 belongs. A long chain not embedded in the bilayer is present. The transmembrane helices are here depicted in yellow or green, being the last one located inside the PTR2 domain. 


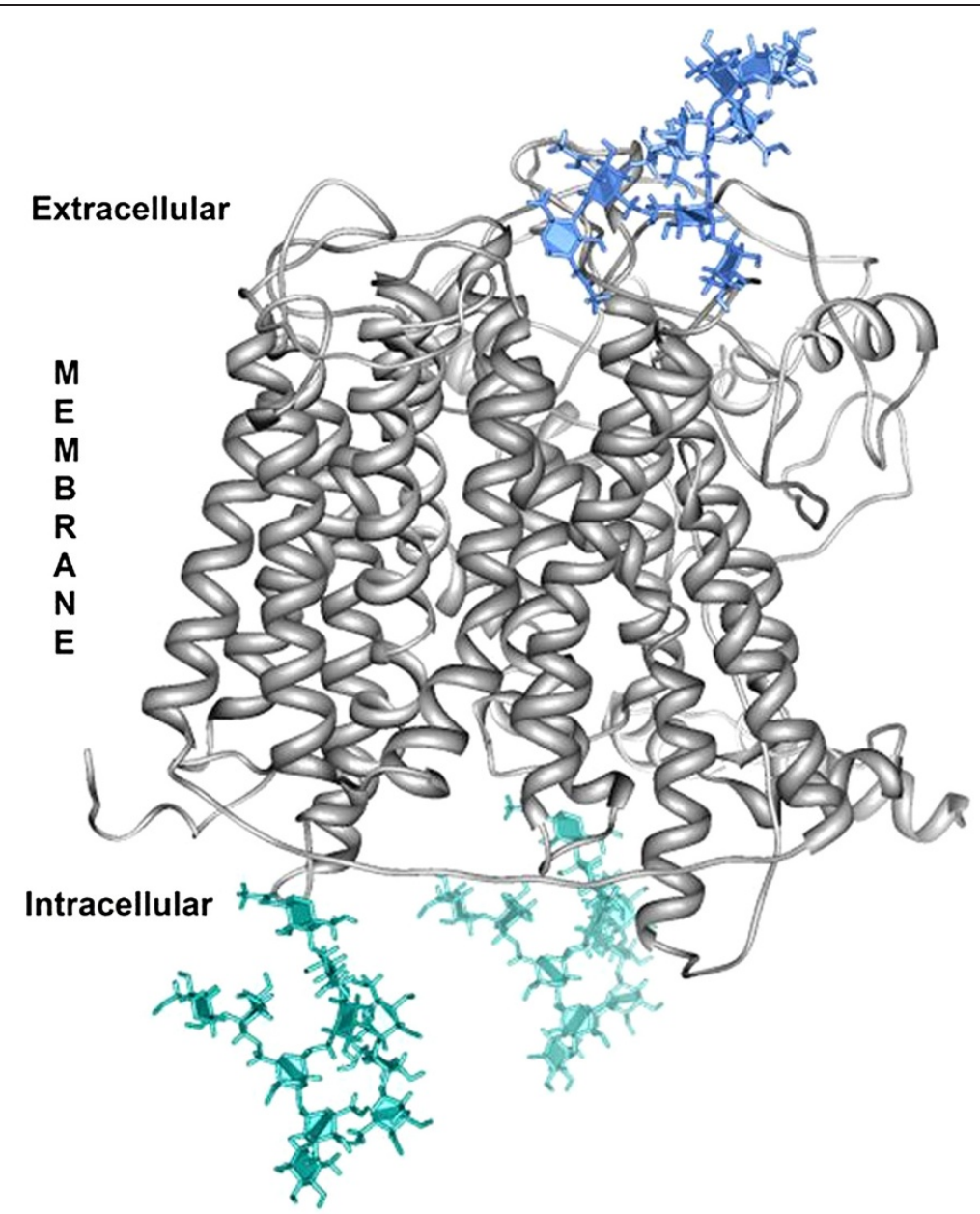

Figure $6 \mathrm{~A}$ constructed 3D model of the PepT1 of D.labrax, in which the accessible N-glycosylation sites are bound to oligomannose. Prediction obtained in silico by the GlyPro (http://www.glycosciences.de/modeling/).

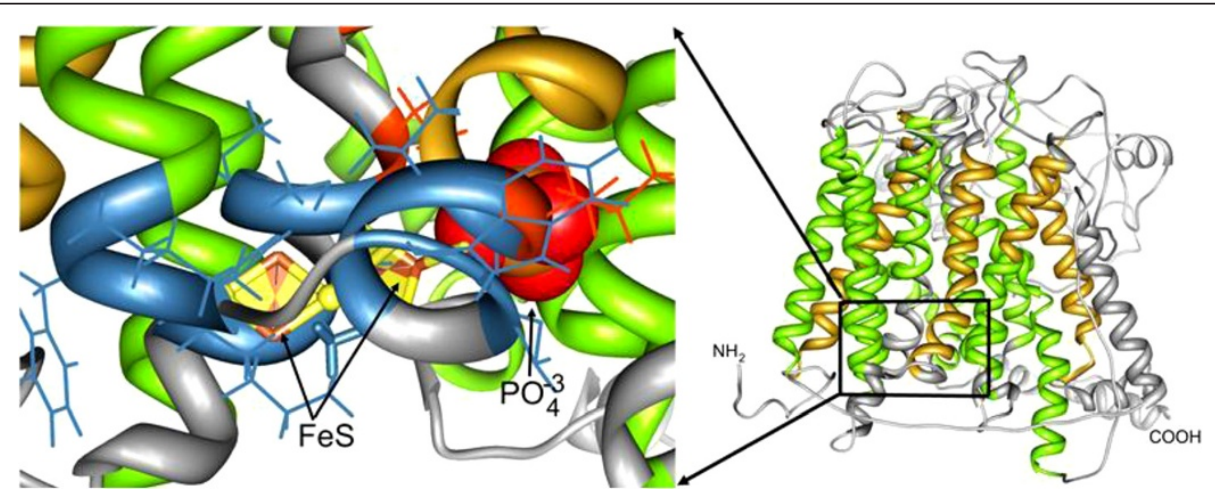

Figure 7 The sites of binding for organic acids and metals in the PepT1 of D.labrax, as predicted by the COFACTOR algorithm. The 3D structure inside the box on the right of the figure was zoomed and rotated to be viewed from the citoplasmic side of the protein, focusing on the binding regions. Blue: residues binding metal clusters, red: residues binding phosphate. 


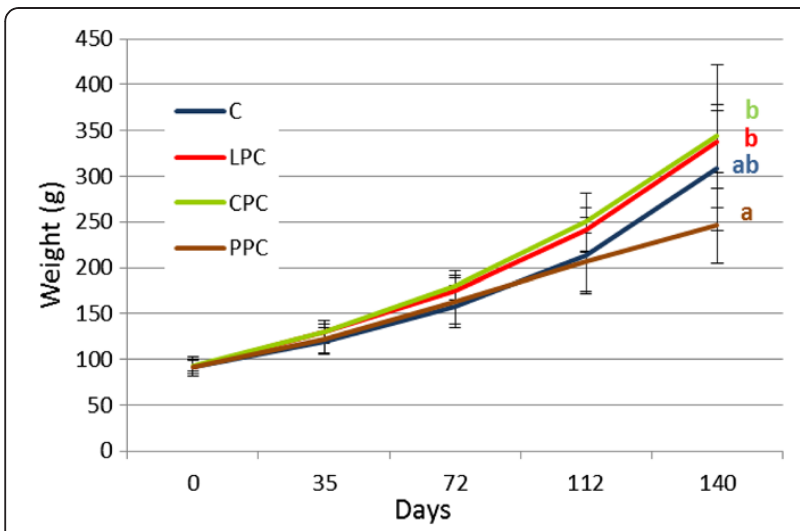

Figure 8 Sea bream body weight during the experiment. Fish were fed for 140 days with one of the following four diet formulations (43\% protein/21\% lipid): control fast growth-promoting diet (C) and three diets with the same formulation but in which 15\% of the fish meal was substituted by protein concentrates either from lupine ( $L P C)$, chick pea $(C P C)$, or green pea (PPC). Significant differences $(p<0.05)$ were only observed for fish body weight after 140 days of feeding.

high levels of expression in segments 1-3 (the first $3 \mathrm{~cm}$ ) of the proximal intestine, lower levels in intestinal segments $4-7$, and very low levels in stomach, brain, spleen and muscle (Figure 9)

\section{PepT1 mRNA copy number in sea bream proximal intestine during the experiment}

The absolute mRNA levels of PepT1 in the proximal intestine of sea bream in response to the feeding trial are presented in Figure 10. As shown, fish fed for 140 days with a diet comprised of $43 \%$ protein and $21 \%$ lipid in which $15 \%$ of the fish meal was substituted by protein concentrates from green pea (PPC) had significantly lower levels of PepT1 transcripts $(\mathrm{p}<0.05)$ in the proximal intestine than the controls. PepT1 transcript levels in fish fed the same diet (43\% protein / $21 \%$ lipid) with $15 \%$ of the fish meal substituted by protein concentrates from lupine (LPC) or chick pea $(\mathrm{CPC})$ were not significantly different from the controls.

\section{Discussion}

A cDNA clone representing the PepT1 in sea bream (Sparus aurata) was successfully identified in the present study. The predicted sea bream PepT1 amino acid

Table 4 Fish weight $(\mathrm{g})$ at the end of the trial after feeding the experimental diets

\begin{tabular}{lcccc}
\hline & C & LPC & CPC & PPC \\
\hline Fish weight & $309.25 \pm$ & $338.30 \pm$ & $343.67 \pm$ & $245.77 \pm$ \\
(g) & $31.90^{\mathrm{ab}}$ & $43.48^{\mathrm{b}}$ & $37.87^{\mathrm{a}}$ & $37.68^{\mathrm{a}}$ \\
\hline
\end{tabular}

Different letters denote statistically significant differences $(p<0.05)$ between treatments. sequence shows extensive sequence similarity to human and other vertebrate PepT1.

Several functionally important sequence motifs described in all known vertebrate PepT1 proteins are also found in the sea bass (Figure 1). They include:

1. The highly conserved histidine residue (H57) (numbering according to human PepT1) (Terada et al. 1996; Chen et al. 2000; Fei et al. 1997). This extracellular residue is considered to be of central importance for PepT1 activity. Indeed, PepT1 was shown to be efficiently inactivated by diethylpyrocarbonate as a histidine-modifying agent (Terada et al. 1996), and mutation of H57 completely inactivated the transporter (Fei et al. 1997; Uchiyama et al. 2003).

2. The H57 adjacent tyrosine residue (Y56), which was also shown to be involved in substrate interaction by reducing the affinity for differently charged dipeptides when mutated to a phenylalanine (Chen et al. 2000).

3. A tyrosine residue (Y64), which appears to be involved in substrate translocation since the subtle change to a phenylalanine residue almost, abolished transport (Chen et al. 2000).

4. Tyr-167, part of the PTR family signature motif, which also seems to be essential for PepT1 activity (Yeung et al. 1998). It is thought to have an essential role in dipeptide uptake (due to the unique chemistry of its phenolic side chain). In fact, replacing it with Ala, Phe, His, Ser, and Cys abolished Gly-Sar uptake of PepT1 (Yeung et al. 1998; Bolger et al. 1998; Kulkarni et al. 2003a).

5. His-121 and His-260, which have been studied together with H111 (H111 is replaced with Lys in sea bream, sea bass, cod, zebrafish, and chicken) due to the $\mathrm{pH}$ dependence of the transport processes. However, mutations did not yield convincing evidence for an essential role in the transport process (Chen et al. 2000; Fei et al. 1997).

6. The highly conserved Ser-164, L168, G173, and I179. These amino acids are responsible for incorrect packaging and/or transport of the protein to the plasma membrane. In fact, the respective mutants S164C, L168C, G173C, and I179C were not expressed on the HEK293 plasma membrane (Kulkarni et al. 2003a).

7. Asn 171, Ser 174, and P182, which play a critical role in substrate binding. The mutations N171C and S174C, respectively, abolished Gly-Sar uptake of PepT1, whereas the mutant P182C showed only $40 \%$ of uptake (Kulkarni et al. 2003a).

8. Arg-282, which in sea bream and other teleosts is replaced with another positively charged amino acid 


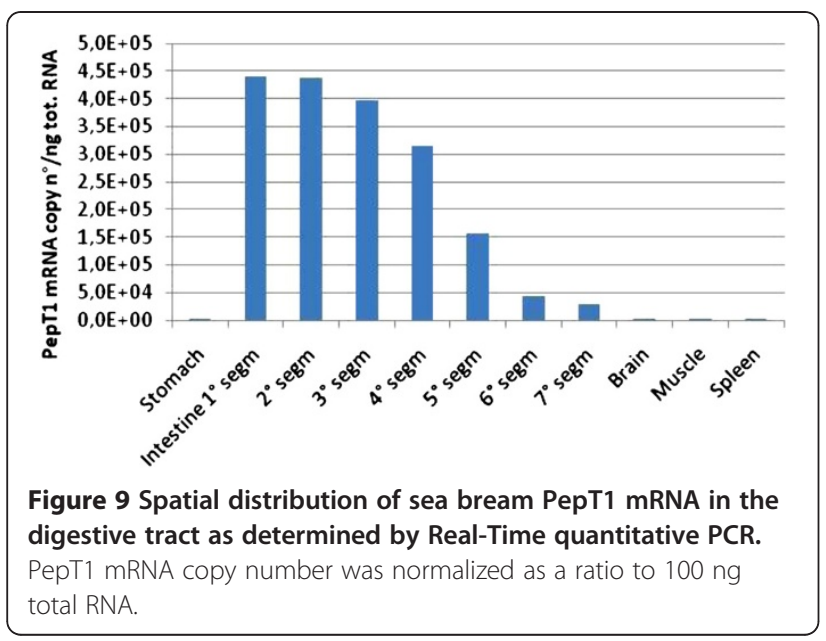

(Lys). It seems that the positive charge is important at this amino acid position. A salt bridge between R282 and D341 may play a role in maximizing the efficiency of substrate translocation. Mutations R282A, R282C, and R282K have a modest effect on Gly-Sar uptake, whereas mutations R282E and R282D show significantly reduced uptake of Gly-Sar (Bolger et al. 1998; Kulkarni et al. 2003b; Kulkarni et al. 2007).

9. Tyr-287 and Met-292, which play critical roles in synthesis and/or folding of the protein. Single cysteine mutation at these positions (Y287C and M292C) was responsible for misfolding of the mutated protein (Kulkarni et al. 2003b).

10. Trp-294, which plays a role in maintaining the structural integrity of the protein. The mutant W294A showed reduced uptake ( 8\%) of Gly-Sar and mutation had a significant effect on the Michaelis-Menten Km value, whereas W294C did not show any reduction in Gly-Sar uptake (Bolger

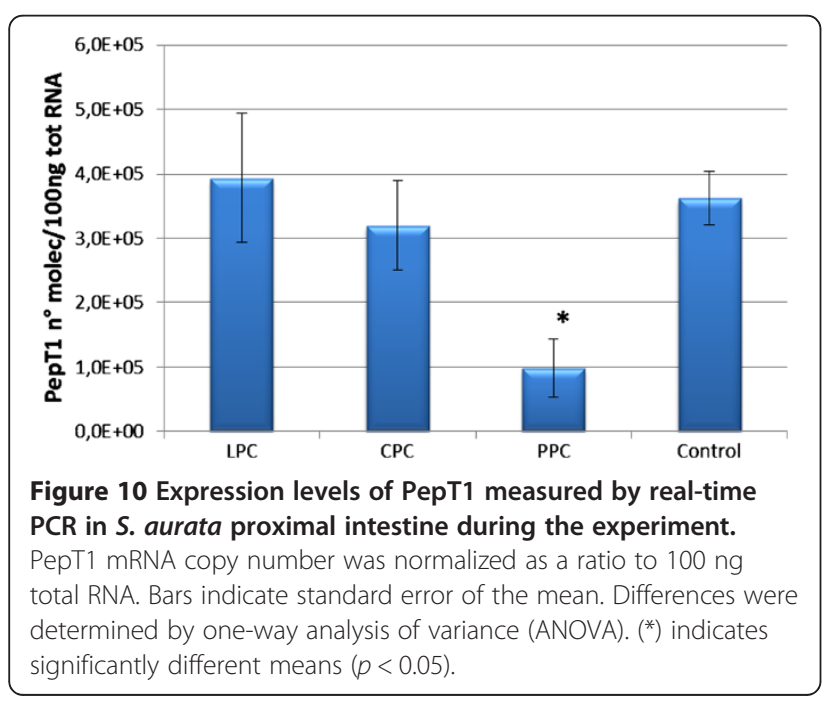

et al. 1998; Kulkarni et al. 2003b). The larger size of the cysteine side chain, compared with that of alanine, sufficiently reflects the steric bulk of the tryptophan side chain and better maintains the correct helical packing.

11. Lys-296 and Phe-297. These residues probably play a structural role in transporter function, as mutants L296C and F297C display negligible uptake of Gly-Sar (Kulkarni et al. 2003b).

12. The highly conserved Asp-341. It seems that the negative charge is important at this amino acid position. A salt bridge between R282 and D341 may play a role in maximizing the efficiency of substrate translocation. Mutations D341A and D341E have a modest effect on Gly-Sar uptake, whereas mutations D341K and D341R show significantly reduced uptake of Gly-Sar (Kulkarni et al. 2007).

13. Pro-586, which may have profound effects on translation, degradation, and/or membrane insertion. Mutant P586L showed reduced transport capacity, lower protein levels, and lower plasma membrane expression (Zhang et al. 2004).

14. Glu-595. Mutant E595A showed reduced uptake of Gly-Sar (Bolger et al. 1998).

The overall high degree of PepT1 sequence conservation through evolution is not only consistent with its essential role for growth and metabolism, but also suggests that its biological action may be equally well conserved. In fact, numerous aspects of digestion and absorption in fish and mammals are similar, demonstrating high conservation of these mechanisms during evolution.

The partial coding sequence of S. aurata PepT1 seems to be very similar to the PepT1 of D. labrax and the two structures align well. The latter is an integral membrane protein, characterized by a series of 12 transmembrane helices, and by a long loop at the external side of the membrane. Both the $\mathrm{N}$ - and $\mathrm{C}$ - terminal are in the cytoplasmic environment. The number of predicted transmembrane regions is 12 instead of 14 of the PepTSo obtained in a prokaryote (Newstead et al. 2011); otherwise, sea bass PepT1 aligns well, although partially, with the template of PepTSo in the PDB repository (2XUT, structural alignment not shown), The length of the helices is approximately $60 \AA$, a value consistent with the lipid bilayer thickness (45-50 ̊). Other features of the two structures also seem to be quite similar, such as the long extramembrane loop at the outer side of the lipid bilayer connecting the ninth and tenth transmembrane segments which is positioned between aa 386 and 581 in PepT1 of D. labrax.

In addition to the transmembrane helices, which characterize the structure as a channel, a PTR2 domain confers on it the features of proton/oligopeptides symporters. The PTR2 subdomain (position 166-178) has 
been characterized in the crystallographically resolved structure of the PepTSo of S.oneidensis, and several binding sites predicted in the structure of D.labrax correspond with those found by the authors who conducted the crystallographic work (Newstead et al. 2011). In this domain fall all the predicted binding sites for phosphate ions and iron clusters.

Sites for post-translational modification have been predicted along the PepT1 protein, including sites of sumoylation, phosphorylation, and $\varepsilon^{-}, \mathrm{O}-$, and N-glycosylation. The two latter ones should be considered with caution, however, because a signal peptide is lacking. Indeed, only one of the three sites, the one at position 120 , could be linked to sugars, this being the only region extending to the extracellular environment, the site of glycosylation in eukaryotes.

In the present work we used real-time PCR technology to carefully assess the impact of dietary manipulation on PepT1 mRNA expression levels in the intestine of sea bream, a marine fish with desirable features for aquaculture and one that is widely cultivated in the Mediterranean area. Our results demonstrate that PepT1 is abundantly expressed in the proximal intestine and pyloric ceca of this species, but it is virtually absent or expressed at very low levels in the stomach and in the distal part of intestine. Thus, it is also likely that, in sea bream, the proximal intestine represents the main expression and production site for PepT1, as also demonstrated in humans (Ford et al. 2003) and other fish species such as sea bass (Terova et al. 2009), cod (Rønnestad et al. 2007), weatherloach (Gonçalves et al. 2007), and zebrafish (Verri et al. 2003). The presence of PepT1 mRNA in the subsequent $10-\mathrm{cm}$ region of the intestinal tissue, at albeit differing levels, is similar to the spatial distribution of PepT1 mRNAs found in sea bass (Terova et al. 2009) and Atlantic cod intestine (Rønnestad et al. 2007). In addition, the relatively very low level of expression in sea bream stomach matches the pattern reported for sea bass and Atlantic cod.

To study the dietary regulation of PepT1 mRNA levels in S. aurata, fish were fed protein from four different sources. After 140 days of feeding, fish fed a diet containing 15\% green pea meal showed a downregulation of PepT1 mRNA levels, together with a lower growth than fish fed the same percentage of either lupin or chick pea meals in the diet. Although field peas (Pisum sativum) have been found to be a promising protein source for several species, such as Atlantic salmon (Aslaksen et al. 2007; Øverland et al. 2009), rainbow trout (Thiessen et al. 2003), sea bass (Gouveia \& Davies 1998), and sea bream (Sánchez-Lozano et al. 2011), its effectiveness must be related to fish size and species, dietary inclusion levels, dietary fish meal content, or raw material processing conditions. For instance, including $10 \%$ untreated pea meal or $20 \%$ pea protein isolate in diets for juvenile milkfish (C. chanos) (Borlongan et al. 2003) or tilapia (O. niloticus) (Schulz et al. 2007) negatively affected fish performance, whereas up to $40 \%$ whole pea meal (Gouveia \& Davies 1998) or up to $30 \%$ extruded pea meal (Gouveia \& Davies 2000) has been successfully included in sea bass diets and up to 37\% extruded pea meal (Pereira \& Oliva-Teles 2002) or $32 \%$ pea protein concentrate in extruded diets (Sánchez-Lozano et al. 2011) in gilthead sea bream. In the present study, $15 \%$ pea protein concentrate tended to reduce growth performance of sea bream, whereas in previous studies conducted in the same species (Sánchez-Lozano et al. 2011), with the same pea protein concentrate and under similar fish size and temperature conditions, it did not affect growth. These different results could be related to the different protein and amino acid profiles of the two diet formulations since, for instance, the latter study included higher amounts of fishmeal.

Interestingly, higher amounts of dietary pea protein concentrate reduce both digestible protein and essential amino acid retention in sea bream (Sánchez-Lozano et al. 2011), which might be at least partially related to a lower di-and tri-peptide transport in the anterior intestine as suggested by the downregulation of PepT1 gene expression in the present study. Furthermore, indigestible carbohydrates, mainly nonstarch polysaccharides (NSPs), are part of the cell wall structure of legumes, reducing feed utilization and growth performance in fish. NSPs are composed predominantly of linked monomers of hexoses and pentoses, such as galactose, glucose, or xylose (Van Barneveld 1999), whereas enzymes such as $\beta$-glucanases or $\beta$-xylanases that digest NSPs are scarce or nonexistent in fish (Kuz'mina 1996). Consequently, the dietary NSPs remain indigestible in fish and may reduce the gastrointestinal passage rate of the food (Storebakken et al. 1999) and interfere with digestion of other dietary nutrients (Storebakken \& Austreng 1987; Refstie et al. 1999). Only very recently, it was found that high inclusion levels of pea protein concentrate (35\%) negatively affect gut health in Atlantic salmon, reducing brush border enzyme activities in the distal intestine of the fish and causing diarrhea associated with a reduction in mucosal fold height and increase in lamina propria width and infiltration (Sinha et al. 2011). Moreover, the presence of saponins in pea protein concentrate, which is highly resistant to the ingredient condition processing (Sinha et al. 2011), also affects gut integrity (Knudsen et al. 2008). Therefore, altered gut integrity caused by several antinutrients found in pea protein concentrate could also be related to the lower expression of PepT1 found in sea bream in the present trial. Further studies are being conducted to clarify this hypothesis.

In conclusion, a cDNA sequence encoding PepT1 in sea bream (Sparus aurata) was isolated and characterized in the present study. The study also demonstrated that PepT1 mRNA copy number is modulated 
by dietary protein sources: including $15 \%$ green pea protein concentrate "downregulates" the levels of PepT1 gene expression in comparison to $15 \%$ lupine or chick pea protein concentrate.

\section{Competing interests}

The authors declare that they have no competing interests.

\section{Authors' contributions}

GT designed the study, participated in molecular cloning and sequencing, carried out real time RT-PCR analysis, and drafted the manuscript; LR and MI carried out the experiment, and performed fish sampling; AGC performed protein in silico analysis; SM participated in molecular cloning and sequencing; GB and MS participated in planning the study. All authors read and approved the final manuscript.

\section{Acknowledgements}

"This work has been funded under the Finlombarda Project and EU seventh Framework Programme by the ARRAINA project N²88925: Advanced Research Initiatives for Nutrition \& Aquaculture.The views expressed in this work are the sole responsibility of the authors and do not necessary reflect the views of the European Commission."

\section{Author details}

'Department of Biotechnology and Life Sciences, University of Insubria, Via J. H. Dunant, 3 - 21100, Varese, Italy. ${ }^{2}$ Inter-University Centre for Research in Protein Biotechnologies "The Protein Factory"- Polytechnic University of Milan and University of Insubria, Varese, Italy. ${ }^{3}$ Grupo de Investigación en Acuicultura, University of Las Palmas de Gran Canaria. Instituto Universitario de Sanidad Animal, Trasmontaña s/n, 35413 Arucas, Las Palmas de Gran Canaria, Canary Islands.

Received: 9 November 2012 Accepted: 14 January 2013 Published: 19 January 2013

\section{References}

Adibi SA (2003) Regulation of expression of the intestinal oligopeptide transporter (PepT-1) in health and disease. Am J Physiol Gastrointest Liver Physiol 285:G779-G788

Altschul SF, Madden TL, Schaffer AA, Zhang, et al. (2003) Gapped BLAST and PSIBLAST: a new generation of protein database search programs. Nucleic Acids Res 25:3389-3402

Aslaksen MA, Kraugerud OF, Penn M, et al. (2007) Screening of nutrient digestibilities and intestinal pathologies in Atlantic salmon, Salmo salar, fed diets with legumes, oilseeds, or cereals. Aquaculture 272:541-555

Blom N, Gammeltoft S, Brunak S (1999) Sequence- and structure-based prediction of eukaryotic protein phosphorylation sites. J Mol Biol 294:1351-1362

Blom N, Sicheritz-Pontén T, Gupta R, et al. (2004) Prediction of post-translational glycosylation and phosphorylation of proteins from the amino acid sequence. Proteomics 4:1633-1649

Bolger MB, Haworth IS, Yeung AK, et al. (1998) Structure, function, and molecular modeling approaches to the study of the intestinal dipeptide transporter PepT1. J Pharm Sci 87:1286-1291

Borlongan IG, Eusebuio PS, Welsh T (2003) Potential of feed pea (Pisum sativum) meal as a protein source in practical diets for milkfish (Chanos chanos Forsskal). Aquaculture 225:89-98

Carter CG, Hauler RC (2000) Fishmeal replacement by plant meals in extruded feeds for Atlantic salmon, Salmo salar L. Aquaculture 185:299-311

Chen XZ, Steel A, Hediger MA (2000) Functional roles of histidine and tyrosine residues in the $\mathrm{H}+-$ peptide transporter PepT1. Biochem Biophys Res Commun 272:726-730

Clements KD, Raubenheimer D (2006) Feeding and nutrition. In: Evans DH, Claiborne JB (ed) The Physiology of fishes, 3rd edition. CRC Press, Boca Raton, pp 47-81

Daniel H, Kottra G (2004) The proton oligopeptide cotransporter family SLC15 in physiology and pharmacology. Pflugers Arch 447:610-618

Daniel H, Spanier B, Kottra G, et al. (2006) From bacteria to man: archaic protondependent peptide transporters at work. Physiology 21:93-102
Drew MD, Borgeson TL, Thiessen DL (2007) A review of processing of feed ingredients to enhance diet digestibility in finfish. Anim Feed Sci Technol 138:118-136

FAO (2010) FishStat Plus - Universal software for fishery statistical time series (online or CD-ROM). available at www.fao.org/fishery/statistics/software/ fishstat/en)

Fei YJ, Kanai Y, Nussberger S, Ganapathy V, et al. (1994) Expression cloning of a mammalian proton-coupled oligopeptide transporter. Nature 368:563-566

Fei YJ, Liu W, Prasad PD, et al. (1997) Identification of the histidyl residue obligatory for the catalytic activity of the human $\mathrm{H}+$ /peptide cotransporters PEPT1 and PEPT2. Biochemistry 36:452-460

Folch J, Lees M, Sloane-Stanley GH (1957) A simple method for the isolation and purification of total lipids from animal tissue. J Biol Chem 226:497-509

Ford D, Howard A, Hirst BH (2003) Expression of the peptide transporter hPepT1 in human colon: a potential route for colonic protein nitrogen and drug absorption. Histochem Cell Biol 119:37-43

Francis G, Makkar HPS, Becker K (2001) Anti-nutritional factors present in plantderived alternate fish feed ingredients and their effects in fish. Aquaculture 199:197-227

Gatlin DM, Barrows FT, Brown P, et al. (2007) Expanding the utilization of sustainable plant products in aquafeeds: a review. Aquac Res 38:551-579

Glencross BD, Booth M, Allan GL (2007) A feed is only as good as its ingredientsa review of ingredient evaluation strategies for aquaculture feeds. Aquac Nutr 13:17-34

Gonçalves AF, Castro LFC, Pereira-Wilson C, et al. (2007) Is there a compromise between nutrient uptake and gas exchange in the gut of Misgurnus anguillicaudatus, an intestinal air-breathing fish? Comp Biochem Physiol Part D 2:345-355

Gouveia A, Davies SJ (1998) Preliminary nutritional evaluation of pea seed meal (Pisum sativum) for juvenile European sea bass (Dicentrarchus labrax). Aquaculture 166:311-320

Gouveia A, Davies SJ (2000) Inclusion of an extruded hulled pea seed meal in diets for juvenile European sea bass (Dicentrarchus labrax). Aquaculture 182:183-193

Hunter S, Jones P, Mitchell A, et al. (2012) InterPro in 2011: New developments in the family and domain prediction database. Nucleic Acids Res 40(D1): D306-D312.

Johansen MB, Kiemer L, Brunak S (2006) Analysis and prediction of mammalian protein glycation. Glycobiology 16:844-853

Julenius K (2007) NetCGlyc 1.0: Prediction of mammalian C-mannosylation sites. Glycobiology 17:868-876

Julenius K, Mølgaard A, Gupta R, et al. (2005) Prediction, conservation analysis and structural characterization of mammalian mucin-type O-glycosylation sites. Glycobiology 15:153-164

Kaushik SJ, Seiliez I (2010) Protein and amino acid nutrition and metabolism in fish: current knowledge and future needs. Aquac Res 41:322-332

Knudsen D, Jutfelt F, Sundh H, et al. (2008) Dietary soya saponins increase gut permeability and play a key role in the onset of soyabeaninduced enteritis in Atlantic salmon (Salmo salar L.). Brit J Nutr 100:120-129

Kulkarni AA, Haworth IS, Lee VHL (2003a) Transmembrane segment 5 of the dipeptide transporter hPepT1 forms a part of the substrate translocation pathway. Biochem Biophys Res Commun 306:177-185

Kulkarni AA, Haworth IS, Uchiyama T, et al. (2003b) Analysis of transmembrane segment 7 of the dipeptide transporter hPepT1 by cysteine-scanning mutagenesis. J Biol Chem 278:51833-51840

Kulkarni AA, Davies DL, Links JS, et al. (2007) A charge pair interaction between Arg282 in transmembrane segment 7 and Asp341 in transmembrane segment 8 of hPepT1. Pharm Res 24:66-72

Kuz'mina W (1996) Influence of age on digestive enzyme activity in some freshwater teleosts. Aquaculture 148:25-37

Letunic I, Doerks T, Bork P (2009) SMART 6: recent updates and new developments. Nucleic Acids Res 37:D229-D232

Mazurkiewicz J (2009) Utilisation of domestic plant components in diets for common carp Cyprinus carpio L. Arch Pol Fish 17:5-39

Newstead S, Drew D, Cameron AD, et al. (2011) Crystal structure of a prokaryotic homologue of the mammalian oligopeptide-proton symporters, PepT1 and PepT2. EMBO J 30:417-426

Ostaszewska T, Dabrowski K, Kamaszewski M, et al. (2010a) The effect of plant protein based diet, supplemented with dipeptide or free amino acids on PepT1, PepT2 expression and digestive tract morphology in common carp (Cyprinus carpio L.). Comp Biochem Physiol Part A 157:158-169 
Ostaszewska T, Kamaszewski M, Grochowski P, et al. (2010b) The effect of peptide absorption on PepT1 gene expression and digestive system hormones in rainbow trout (Oncorhynchus mykiss). Comp Biochem Physiol Part A 155:107-114

$\varnothing$ verland M, Sørensen M, Storebakken T, et al. (2009) Pea protein concentrate substituting fish meal or soybean meal in diets for Atlantic salmon (Salmo salar)-Effect on growth performance, nutrient digestibility, carcass composition, gut health, and physical feed quality. Aquaculture 288:305-311

Pereira H, Oliva-Teles A (2002) Utilization of raw and gelatinized starch by European sea bass (Dicentrarchus labrax) juveniles. Aquaculture 205:287-299

Pettersen EF, Goddard TD, Huang CC, et al. (2004) UCSF Chimera-a visualization system for exploratory research and analysis. J Comput Chem 25:1605-1612

Pierleoni A, Indio V, Savojardo C, et al. (2011) A pipeline for the annotation of eukaryotic membrane proteins. Nucleic Acids Res 39:W375-W380

Refstie S, Svihus B, Shearer KD, et al. (1999) Nutrient digestibility in Atlantic salmon and broiler chickens related to viscosity and non-starch polysaccharide content in different soybean products. Aquaculture 79:331-345

Ren J, Gao X, Jin C, et al. (2009) Systematic study of protein sumoylation: Development of a site-specific predictor of SUMOsp 2.0. Proteomics 9:3409-3412

Rønnestad I, Gavaia PJ, Viegas CSB, et al. (2007) Cloning, tissue expression and comparative aspects of the Atlantic cod (Gadus morhua L.) oligopeptide transporter PepT1. J Exp Biol 210:3883-3896

Roy A, Kucukural A, Zhang Y (2010) I-TASSER: a unified platform for automated protein structure and function prediction. Nat Protoc 5:725-738

Sánchez-Lozano NB, Martínez-Llorens S, Tomás-Vidal A, et al. (2011) Amino acid retention of gilthead sea bream (Sparus aurata, L.) fed a pea protein concentrate. Aquacult Nutr 17:604-614

Schultz J, Milpetz F, Bork M, et al. (1998) SMART, a simple modular architecture research tool: identification of signaling domains. Proc Natl Acad Sci USA 95:5857-5864

Schulz C, Wickert M, Kijora C, Ogunji J, et al. (2007) Evaluation of pea protein isolate as alternative protein source in diets for juvenile tilapia (Oreochromis niloticus). Aquacult Res 38:537-545

Sinha AK, Kumar V, Makkar HPS, et al. (2011) Non-starch polysaccharides and thei role in fish nutrition - A review. Food Chem 127:1409-1426

Storebakken T, Austreng E (1987) Binders in fish feeds: II. Effect of different alginates on digestibility of macronutrients in rainbow trout. Aquaculture 60:121-131

Storebakken T, Kvien IS, Shearer KD, et al. (1999) Estimation of gastrointestinal evacuation rate in Atlantic salmon (Salmo salar) using inert markers and collection of faeces by sieving: evacuation of diets with fish meal, soybean meal or bacterial meal. Aquaculture 172:291-299

Tacon AGJ, Metian M (2008) Global overview on the use of fish meal and fish oil in industrially compounded aquafeeds: Trends and future prospects. Aquaculture 285:146-158

Terada T, Saito H, Mukai M, et al. (1996) Identification of the histidine residues involved in substrate recognition by a rat $\mathrm{H}+$ /peptide cotransporter, PepT1. FEBS Lett 394:196-200

Terova G, Corà S, Verri T, et al. (2009) Impact of feed availability on PepT1 mRNA expression levels in sea bass (Dicentrarchus labrax). Aquaculture 294:288-299

Thiessen DL, Campbell GL, Adelizi PD (2003) Digestibility and growth performance of juvenile rainbow trout (Oncorhynchus mykiss) fed with pea and canola products. Aquacult Nutr 9:67-75

Uchiyama T, Kulkarni AA, Davies DL, et al. (2003) Biophysical evidence for His57 as a proton-binding site in the mammalian intestinal transporter hPepT1. Pharm Res 20:1911-1916

Van Barneveld RJ (1999) Understanding the nutritional chemistry of lupin (Lupinus spp.) seed to improve livestock production efficiency. Nutr Res Rev 12:203-230

Verri T, Kottra G, Romano A, et al. (2003) Molecular and functional characterization of the zebrafish (Danio rerio) PepT1-type peptide transporter. FEBS Lett 549:115-122

Yeung AK, Basu SK, Wu SK, et al. (1998) Molecular identification of a role for tyrosine 167 in the function of the human intestinal proton-coupled dipeptide transporter (hPepT1). Biochem Biophys Res Commun 250:103-107

Yuen BBH, Wong CKC, Woo NYS, Au DWT (2007) Induction and recovery of morphofunctional changes in the intestine of juvenile carnivorous fish (Epinephelus coioides) upon exposure to foodborne benzo[a]pyrene. Aquat Toxicol 82:181-194
Zhang Y (2007) Template-based modeling and free modeling by I-TASSER in CASP7. Proteins 69(Suppl. 8):108-117

Zhang Y (2008) I-TASSER server for protein 3D structure prediction. BMC Bioinformatics 9:40

Zhang EY, Fu DJ, Pak YA, et al. (2004) Genetic Polymorphisms in human protondependent dipeptide transporter PepT1: implications for the functional role of Pro(586). J Pharmacol Exp Ther 310:437-445

doi:10.1186/2193-1801-2-17

Cite this article as: Terova et al:: PepT1 mRNA expression levels in sea bream (Sparus aurata) fed different plant protein sources. SpringerPlus 2013 2:17.

\section{Submit your manuscript to a SpringerOpen ${ }^{\odot}$ journal and benefit from:}

- Convenient online submission

- Rigorous peer review

- Immediate publication on acceptance

- Open access: articles freely available online

- High visibility within the field

- Retaining the copyright to your article

Submit your next manuscript at $>$ springeropen.com 